\title{
Legal Ethics for a Fragmented Society: Between Professional and Personal
}

Allan C. Hutchinson

Osgoode Hall Law School of York University, ahutchinson@osgoode.yorku.ca

Source Publication:

International Journal of the Legal Profession. Volume 5, Numbers 2/3 (1998), p. 175-192.

Follow this and additional works at: https://digitalcommons.osgoode.yorku.ca/scholarly_works c) (i) $(9)$

This work is licensed under a Creative Commons Attribution-Noncommercial-No Derivative Works 4.0 License.

\section{Recommended Citation}

Hutchinson, Allan C. "Legal Ethics for a Fragmented Society: Between Professional and Personal." International Journal of the Legal Profession 5.2/3 (1998): 175-192.

This Article is brought to you for free and open access by the Faculty Scholarship at Osgoode Digital Commons. It has been accepted for inclusion in Articles \& Book Chapters by an authorized administrator of Osgoode Digital Commons. 


\title{
Legal ethics for a fragmented society: between professional and personal
}

\author{
ALLAN C. HUTCHINSON* \\ Osgoode Hall Law School, York University, Ontario, Canada
}

The lawyer is always in a hurry. He has become keen and shrewd; ... but his soul is small and righteous.

Plato

The legal profession has never been much loved. From Plato through Charles Dickens to Tom Wolfe, literature attests eloquently to its impugned status. As much envied as reviled, the reputation and prestige of lawyers is now considered by many to be at an all-time low. Its image as a noble and honourable profession is in tatters. Society tends to view lawyers as a rich and elite profession that is more interested in its own pocketbook than the public interest. The number of savage jokes about lawyers would be funny if they did not touch a raw nerve: after all, humour is not so much an escape from reality as from despair. In receipt of a professional monopoly, lawyers are considered self-interested and undeserving of their privileged right to govern themselves. Indeed, the legal profession is seen to epitomise George Bernard Shaw's quip that "every profession is a conspiracy against the laity". However, while a similar sense of dissatisfaction and anxiety is evident inside the less

\footnotetext{
* Address for correspondence: Allan C. Hutchinson, Osgoode Hall Law School, York University, 4700 Keele Street, North York, Ontario, Canada M3J 1P3.
} 
crass sectors of the profession, the more familiar refrain is that any crisis is attributable to the fact that the profession once had a shared sense of legal ethics and professional responsibility which has been lost. Having become too much a corporate business than a public vocation, it is urged that the legal profession must revert to this traditional esprit de corps if it is to regain its respectability and stature: lawyers must reclaim the ethical legacy of noble lawyers past.

Like most expressions of nostalgia, this characterisation of the perceived crisis and its proffered solution has some grounding in reality. But it is as much a pious pretence as a genuine remedy for institutional ills. The profession has indeed become more business-like in operation and, as a result, more corporate in attitude; legal services are treated as one more commodity to be bought and sold in the marketplace. This tendency has been facilitated by the traditional view of legal ethics which puts service-the belief that lawyers do not have responsibility for the law and its development, but only for the satisfaction of their clients' wishes-before justice. ${ }^{1}$ Moreover, it is most definitely not the case that the cure for the perceived professional blight is a return to the values and standards of yesteryear. On the contrary, what is required is the development of a fresh approach to legal ethics that is both sensitive to the changing shape and style of modem legal practice and, at the same time, demands that lawyers aspire to a more diverse and critical selfimage. Accordingly, mindful that the homogeneity of lawyers is beginning to be replaced by more diverse personnel, the theme of this article will be to assess the implications that the challenge of a fragmented society and legal profession holds for the critical development of a transformed practice of professional responsibility. 
After sketching the different demands and design of a fragmented society, I will concentrate on how the legal profession itself is beginning to fragment and what that means for existing accounts of legal ethics. In particular, my focus will be on how it is vital to rethink present understandings of lawyers' ethical personae and to canvass future possibilities for a more compelling vision of a professional modus vivendi. Emphasising the Canadian predicament, I will argue that a fragmented society deserves a fragmented legal profession which, in tum, warrants a more fragmented idea and implementation of legal ethics. There must be a shift of emphasis from professional regulation to personal responsibility. As well as indicating the shape and direction that such a revised ethical stance might take, I explore the more substantive and concrete consequences for legal education and professional practice. My ambition is not to promote a particular set of ethical outcomes or inculcate a specific mode of professional responsibility; it is to challenge students and lawyers to develop a professional modus vivendi of their own that constructs as it constantly challenges and re-works an appropriate professional attitude and practice. In the same way that there is no one or unchanging way to be a good person, there is no one or unchanging way to be a good lawyer: each and every lawyer must be capable of developing a style and substance of lawyering that incorporates a continuing dialogue-with oneself, clients, other lawyers, other professionals, and the community at large-about what counts as good lawyering. The central question is whether it is ever acceptable that lawyers might, can or should act in a professional capacity in such a way that it would be contrary to their own moral values. ${ }^{2}$ 


\section{Traditional ethics}

The traditional image of the ethical lawyer has remained largely static and unchanged for many decades. It is centred on the idea that lawyers are super-technocrats; they possess an expert set of talents and techniques which they deploy for the advantage of those people who hire them. Regarding themselves as being neutral on the substance and form of the law, their task is very much to apply the law, perhaps to criticise it a little, but most certainly not to make it. Lawyers' commitment is to the legal system which, even when they are working around and within it, must be accepted as given. Almost indifferent to who their clients are, lawyers think of themselves as more chosen than choosing. The relationship between lawyer and client is built upon trust and respect: clients are to trust lawyers to act in the clients' best interests and, in.return, lawyers will respect the clients' autonomy. It is not for lawyers to impinge upon the clients' autonomy, but to act on behalf of the clients to realise their interests and inspirations. The lawyer is expected to treat all clients exactly the same in the sense that they are each citizens who have had their rights infringed and want relief or vindication. Advocacy and action tends, therefore, to be standardised and routinised. Insofar as lawyer and clients are from different cultures and classes, lawyers are expected to bridge the gap by personal empathy and professional solidarity.

Although the validity and merit of this ethical self-image is almost taken for granted by most lawyers and jurists, it is based on certain foundational premises about law, society and ways of thinking about them. Like all operating assumptions, they are more controversial than many traditionalists care to think or acknowledge. Some of the more important ones 
are that:

- Law is objective and certain-the hallmark of good lawyers is considered to be found in their cultivation of rule-craft in which the ability to identify the extant rules of the legal system and apply them to particular situations is paramount. As such, law has considerable stability and independence, offers operationally determinate guidance to the trained lawyer, and is institutionally distinct from the more open-minded disputations around ideological politics.

- All clients are to be treated the same-all clients have pre-established interests and come to lawyers to have their rights vindicated. The task of lawyers is to accept any clients that seek their services and to utilise their common expertise in pursuing the interests of their clients in such a way that justice will be done and the Rule of Law upheld.

- The criminal trial is the paradigm of legal responsibility-the basic dynamic of the legal system is traceable to the adversarial contest between individual and state in the criminal process. While the roles of lawyers vary in civil trials and non-adversarial contexts, their basic responsibilities can be extrapolated from the institutional setting of the criminal brief.

- Lawyering is an apolitical undertaking-lawyers pursue their clients' interests through the extant rules, procedures and venues of law: overt politicisation is severely frowned upon. While lawyers engage in struggles that arise in and have consequences for politics, lawyering is a neutral exercise that does not implicate lawyers in any political process and that insists upon no commitment to any particular ideology.

As attractive and as comforting as this traditional image of legal ethics and 
professional responsibility may be to legal practitioners, its problems are manifest and manifold. It fails theoretically, empirically and ideologically-it is based upon a formalistic theory of law that is largely discredited and defunct as a serious attempt to understand law and its operation. It describes a version of legal practice that no longer has any empirical validity or historical accuracy, if it ever did have; and it defends both its informing theory and governing practice of lawyering as apolitical in such a way that merely serves to underline its very definite ideological commitments. ${ }^{3}$ However, for present purposes of highlighting the traditional model of the ethical lawyer, there are two underlying premises which are most pertinent--one is the notion of a reasonably homogenous and uniform legal profession and the other is the idea of a role-differentiated and rule-based morality.

First, the traditional image of the ethical lawyer asks lawyers to subordinate their personal morality and identity to the standardised requirements of a role-defined rule-based morality. It assumes that legal professionals will appreciate and actualise the demands of a roledifferentiated morality in which lawyers' duties are exclusively bounded by the law and the professional code of conduct on one side and the clients' interests on the other. It is a two-dimensional moral universe in which lawyers are no more expected to intrude their own personal values than actors or butlers in the performance of their duties. ${ }^{4}$ Such a notion allows persons to claim moral legitimacy for actions that might be considered illegitimate in other, different roles and contexts. Moreover, once in this professional role, lawyers are required to treat morality in the same way that they deal with law-as an exhaustive body of rules that can be formally applied to resolve the most recalcitrant of difficulties and dilemmas. Consequently, in the 
traditional approach, there is very little space for reflection or engagement; reference to the professional codes is intended to provide definitive and authoritative answers.

Secondly, the traditional image and professional codes are (not so subtly) underpinned with the view of the white, male lawyer as an independent professional who deals with a range of legal tasks and who is driven as much by civic pride as commercial ambition; lawyers are a homogeneous group who engage in broadly similar work. This notion of the fungible lawyer who inhabits, with only slight variation and adaptation, all the offices and activities throughout society is a myth. The reality is that, while such anachronisms exist, they are the exception rather than the rule. Indeed, there is no longer one image of the lawyer; they are an increasingly heterogenous and stratified bunch whose backgrounds, ambitions and standards are much less uniform than was previously the case. However, the legal profession is becoming more diversified, it remains a very stratified profession in which the white male lawyers still exercise the most control over the regulation and self-image of the profession. It is to the critique of these two premises-the existence of a homogenous legal profession and the worth of a role-differentiated and rulebased morality-that I now turn.

\section{Fragmented profession}

Whether there ever has been one type of lawyer or one kind of legal practice, Canada's legal profession at the end of the twentieth century comprises many types of lawyers and many kinds of legal practice. Although the Canadian literature is not as extensive or as thorough as that of the United Kingdom 
and the United States, ${ }^{5}$ there is ample evidence to support the developing view that talk of one legal profession is almost becoming fanciful; there is such a horizontally and vertically differentiated set of people and organisations engaging in different sorts of legal practice that generalisations are as unfounded as they are misleading. The profession is differentiated into megafirms, smaller partnerships, and single practitioners, not to mention government lawyers and the like; there is little shared experience, little interaction between them and each operate in line within different cultures and norms. Indeed, the idea that there is a unified legal profession is not only mythical, but has an insidious bearing on legal ethics. From its elite status at Confederation, the legal profession has become increasingly fragmented, both in terms of diversity (different people and forms of organisation) and stratification (a hierarchical order to such diversity). Unfortunately, there has been a marked tendency for the benefits of diversity to be neutralised by the imposition of stratification: the new and diverse personnel are relegated to the marginalised periphery of the legal profession. While the profession has diversified, the typical lawyer remains male, white, Englishspeaking, early middle-aged, and Christian: other lawyers who deviate from this norm are greater in number, but still less powerful in prestige and influence. ${ }^{6}$

Legal practice is shaped by many factors, both external and internal to it. In recent decades, the Canadian legal profession has been strongly influenced by a variety of environmental forces over which it has very little control: decreasing state regulation; the juridification of dispute-resolution; the re-structuring of the economy; the extent of globalisation; and the spread of computerisation and information technology. Not surprisingly, these external forces have been mediated through a set of internal filters that affect their 
impact on the workings of the legal profession. ${ }^{7}$ The first thing to note is that there is no longer a Canadian legal profession-there are many different ones, ranging from the solo practice to the large corporate bureaucracy through the small partnerships and government lawyers. The days of the fungible lawyer or legal practice are long gone. There is a wide range of lawyering types who engage in a wide variety of practices. Who does law (men and women, young and old, black and white, etc.), where they do it (office towers, shopping malls, clinics, home basements, government offices, mobile vans, etc.), how they do it (with entrepreneurial flair, part-time, on a shoe-string, as big business, etc.), who they do it for (aboriginal people, rich individuals, international conglomerates, homeless, small businesses, etc.), and what they do it for (subsistence income, personal satisfaction, enormous income, political influence, etc.) has gone through a transformation. However, as well as there being a greater diversification of the legal profession, there has been a marked increase in the stratification. Lawyers are distinguished not only by what they do, but the professional satisfaction, financial reward, public esteem and political influence that they experience.

The size of the Canadian legal profession increased by $430 \%$ from 1931 to 1986 and went from 2,710 members in 1986 to 49,680 in 1996. This translated in Ontario into the lawyer/population ratio jumping from 1/1142 in 1960 to $1 / 574$ in 1981 . As Figures 1 and 2 show, the proportion of different ethnicities, genders, nationalities and religious affiliations has changed significantly: while the percentage of lawyers born in Canada has reduced slightly, the general diversity has improved significantly. As regards the organisation and hierarchy of legal practice, Figures 3 and 4 reflect the increasing variety of ways in which lawyers practice law. However, 


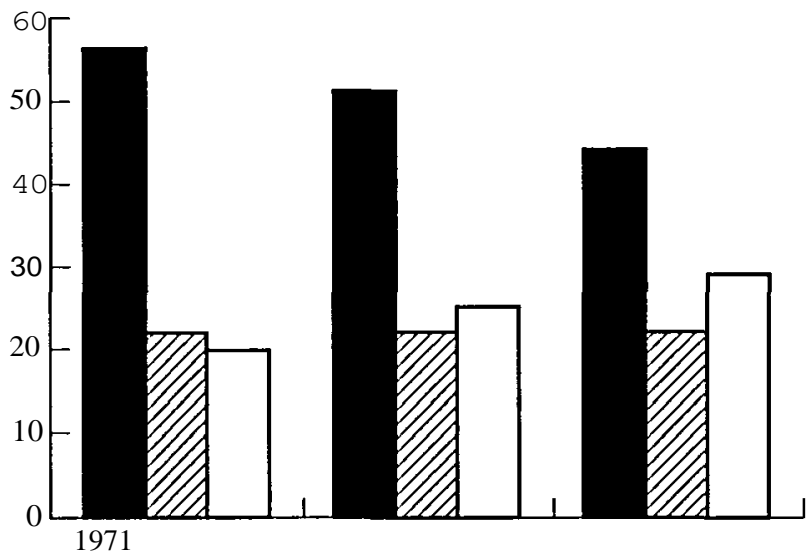

1981

Figure 1.Lawyers, ethnic background (IIBritish; French; D Other). Source: Statistics Canada, Census of Canada, decennial publications.

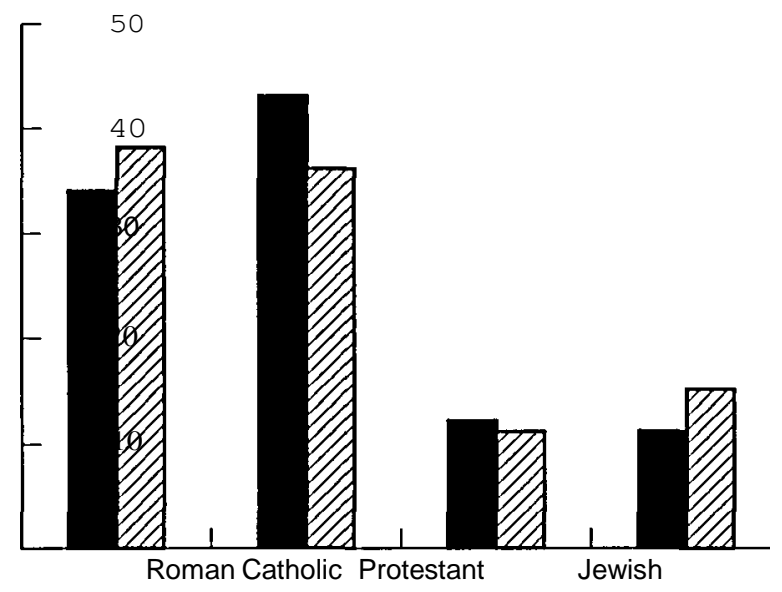

Other or none

Figure 2. Religion of lawyers (11 1971; $\mathrm{M}$ 1981). (Note: there was no question about religion in the 1986 census.) Source: Statistics Canada, Census of Canada, 1971 and 1981, special tabulations.

there are certain forms of legal practice that are much more prestigious than others and certain differences have some definite implications for legal ethics. In particular, not only do the elite firms have greater access to the law society bodies that develop the rules and culture of the profession, but the sole practitioner is much more likely to be subject to formal monitoring by the 
profession. In short, big-time lawyers establish the standards of good lawyering and ensure that small-time lawyers live up to them. A refusal to abandon the assumption of a homogeneous profession, even in the face of a statistically diverse one, will not only be mismatched to the needs of the public and the profession, but will also exacerbate stratification and hierarchy in the profession.

These changes worked by the external forces operating on the structure and

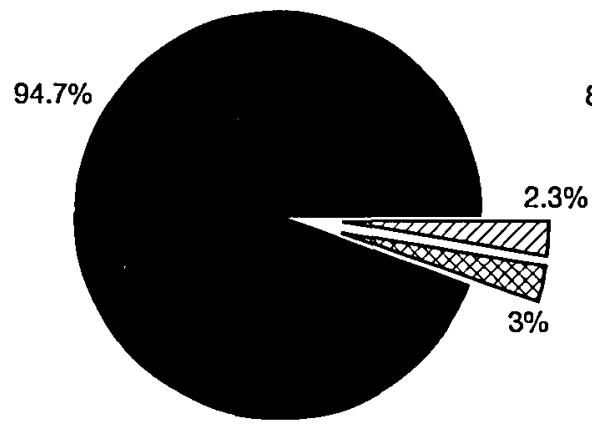

1931

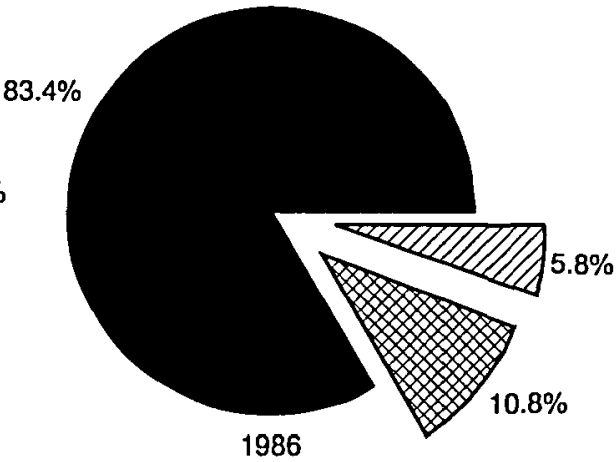

1986

Figure 3. Industrial distribution of lawyers (II Community, Business \& Personal Services; 1111 Public Administration; Private Industry).

Source: Statistics Canada, Census of Canada, Occupation by Industry, decennial publications; special tabulations for 1986.

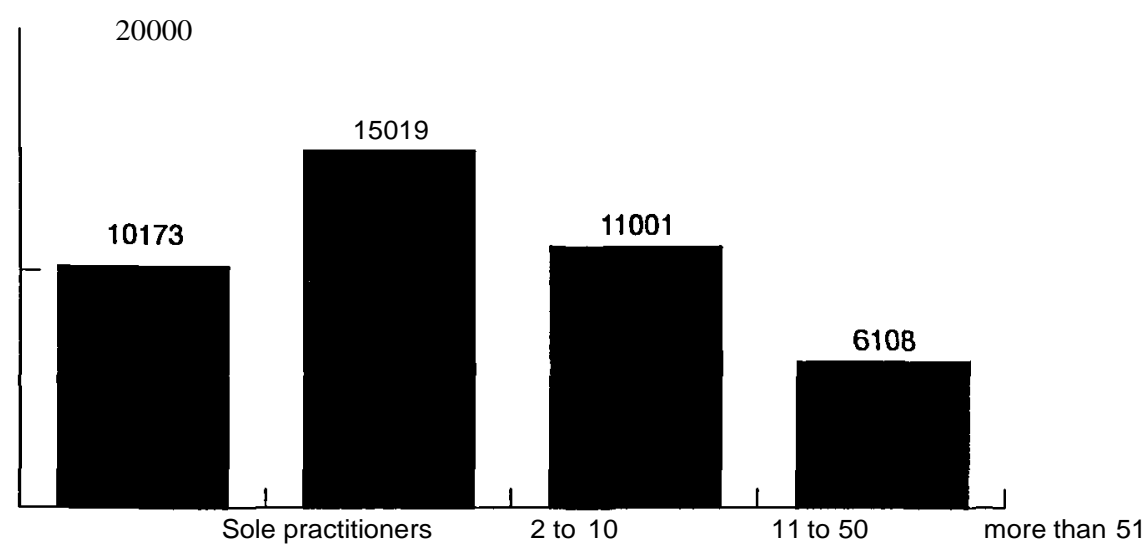

Figure 4. Distribution of lawyers injinns and solo practice. Source: Federation of Law Societies in Canada, 1996Statistics. 
work of the legal profession and its internal re-organisation and economy have exerted a strong influence on the governance of the profession and the status of legal ethics. As well as important changes in the nature of law and legal education, the different kinds of legal practice mean that the effort to impose a unitary and uniform system of governance on the legal profession is coming under increasing pressure; the different constituencies agitate for very different initiatives and regimes of collective supervision. The debates over continuing legal accreditation, articling, diversity, and malpractice insurance pit one part of the profession squarely against another. At its most extreme, this unrest and division of interests will likely precipitate moves to remove or, at least, curtail the legal profession's monopoly. As for legal ethics, the consequences of these external and internal pressures are affecting both the establishment of shared common norms and their enforcement. There are a series of small sub-cultures that have developed and standardised their own standards and expectations for ethical behaviour: small-town family lawyers operate in a different milieu to the metropolitan corporate deal-makers. In this kind of professional climate, it is even more difficult to sustain the idea that there are a common set of rules and expectations that can both educate and discipline the legal profession in matters of ethical practice.

\section{Roles and rules}

Traditional views and understandings about what it means to be an ethical lawyer are based upon narrow and unrealistic assumptions about what ethical decisions address and involve, who lawyers are and what they do, what constitutes law, and the professional contexts in which these arise. To be a 
legal professional is to enter into a community that has developed a shared set of normative practices and expectations that it is authorised or prepared to enforce in the face of recalcitrant behaviour. While several devices are used to curb and monitor lawyers' behaviour, codes of professional conduct lie at the heart of the profession's focus on legal ethics and responsibility. The reasons for having codes of professional conduct are fairly obvious-to educate lawyers on communal expectations; to affect behaviour; and to offer a basis for discipline. However, law societies have tended to develop and adapt their professional rules in response to problems that arise: it has been a reactive and unambitious approach that lacks any underlying direction or purpose. Some critics have insisted that such codes are little more than ethical windowdressing; they serve to legitimate what lawyers do and impose control over economic competition. What passes for talk of ethical standards is, at best, a stylised form of professional regulation and, at worst, a self-serving paean to professional prestige. ${ }^{8}$ In short, professional bodies are, through their codes and rules, often as interested in enforcing collegial conformity as fostering a sense of ethical purpose; there is a lingering suspicion that the rules do more to promote professional self-interest and little to affect ethical behaviour or debate among practising lawyers.

To read any of the provincial codes of professional conduct is to encounter a series of pronouncements that are long on righteous aspiration and vague generalities, but short on serious instruction and concrete guidance. It is a case of not seeing the ethical forest for the law-like trees. Although lawyers are weighed down with discrete and detailed directives on this or that matter, there is little to counsel the floundering or jaded lawyer in establishing an overall and professional modus vivendi. Like the formalist 
lawyering that many claim to embody and extol, ethics is reduced to a technical compliance with a set of simple do's and don'ts-more of a shopping list than a genuine effort to inculcate a style and substance of legal practice that addresses the whole lawyer not merely the occasional legal transaction. It is as much about conformity as it is about conscience. Lawyers approach ethics in the same way that they approach law-as a set of rules to be mastered and manipulated to serve the purpose in hand. Indeed, under the sway of a legalistic mentality, the teaching of legal ethics and responsibility is more like a course on office management; it is as much about techniques in filing and organisation as it is about thinking through dilemmas and difficulties.

Even assuming that the various codes are treated as representing a serious attempt at ethical instruction and control, an exclusive concentration on the rules is misplaced. There is little to be gained by providing an elaborate and exhaustive annotation of the rules of professional conduct because, not only has this been adequately done, but it ignores the very real fact that the influence on lawyers' daily routines and rituals is small: the constant attention to and re-drafting of the rules is of decreasing marginal utility. ${ }^{9}$ Nevertheless, this does not mean that the codes have no place in any appreciation of legal ethics and their actual improvement; they are an important resource in discussion and decision-making, but they are not a decisive or determinate play-book that relieves lawyers of the personal responsibility to develop an ethical style and substance of legal practice. The codes are a site at which ethical debate can be joined and developed. As with many catalogues of rights and responsibilities, there will be competing and occasionally contradictory imperatives; duties to one's clients might suggest a different course of action to those recommended by the lawyers' 
responsibilities as an officer of the court. In some instances, the rules demand that lawyers "must" make certain choices and give priority to certain actions. However, the rules more often offer no definite resolution and simply provide a rudimentary framework within which lawyers can debate and develop an ethical practice of law. It is important therefore to remember that the rules do not and cannot relieve lawyers of the continuing responsibility to exercise their own professional and moral judgement about the appropriate course to follow. In many ways, therefore, the interpretation of the professional codes and rules resembles other modes of legal interpretation. In the same way that the meaning of constitutional or statutory law is not fixed or exhausted by their textual renderings, so the requirements of professional responsibility and legal ethics are not reducible to the four textual corners of the codes. Both require reference to a wide range of interpretive aids and sources, including conventions, customs, tradition, cultural expectations, institutional norms, and social values. As with teaching legal doctrine generally, little is achieved by simply asking students to learn rote-like the rules of professional conduct without also providing them with some critical framework within which to understand how those particular rules came into being, what they are intended to do, etc. It is the same with legal ethics. If students are taught only the rules of professional conduct, they will be ill-prepared to adapt those sweeping injunctions to changing circumstances or to respond to uncertainty in the rules' meaning or application. As so much contemporary jurisprudence insists, it is never possible simply to "follow the rules" as the question of what "the rules" mean and what it means to "follow" them are never beyond dispute. ${ }^{10}$ Legal interpretation is an ungrounded practice in that it cannot be engaged in 
without taking a stand on values or choices that are themselves always open to challenge; the distinction between "following the rules" and "following one's conscience" is neither as clear nor as uncontroversial as traditionalists suggest. Accordingly, the suggestion that a viable and satisfying legal ethics can be maintained by adopting the professional role of a ruleordered mentality is sorely mistaken.

As presently practised, legal ethics is more than unthinking compliance with the prevailing rules of professional conduct in order to avoid discipline or disrepute; it already involves resort to personal conscience in order to determine what is a professionally appropriate course of action. ${ }^{11}$ Like general ethics, legal ethics is contextual in the sense that it involves particular people in particular situations making difficult decisions with particular time constraints, with imperfect information and with particular consequences for particular people. And, of course, there is no context of contexts that allows people to fix once and for all their obligations and actions when acting in personal or professional roles. There are few right answers that stand outside any context or debate. The traditional understandings and expectations are after all nothing more (or less) than the accumulated practices of lawyers that have been affixed with institutional authority; lawyers can and should contribute to as much as respond to the developing culture oflawyering. In this way, they are in a better position to cultivate a modus vivendi that enables them to bring together the promptings of their personal conscience with the demands of their professional occupation. Legal ethics ought to be an active meditation on law and lawyering rather than a passive and neutral adherence to a professional code. Indeed, the rules are less of a set of directives from which lawyers can draw clear guidance, but more a collection of practical 
wisdom with which lawyers can engage and contest. ${ }^{12}$ Accordingly, compliance with law, in both its spirit and letter, does not amount to acceptable ethical behaviour: professional morality is more than law-abiding conformity. The fact that most decisions and practices by lawyers allow for a variety of manoeuvres or results means that lawyers need to develop a professional facility to comprehend and handle such challenges; there is rarely an obvious or incontestable path to follow.

Although it is often forgotten by most lawyers, the study of legal ethics is a branch of ethics generally; it is not a subject unto itself. At its broadest, ethics involves a meditation on what is wrong and right and, most importantly, how such standards are arrived at and validated. Traditionally, the task was to elaborate and justify a set of ethical norms that provide an authoritative code that people could consult and follow in resolving difficult dilemmas. However, faith in the possibility of sketching such a body of enduring and universally valid rules has been waning. There is now the less absolutist and more sceptical acceptance that ethics is a much more situational practice that cannot claim objective or neutral justification. As with general ethics, the prevailing standards of right and wrong do not exhaust ethical inquiry into legal professionals' behaviour; those standards must themselves be subject to scrutiny and challenge. The different ethical theories seek to examine critically conventional moral judgements and practices; they offer methods and devices through which to justify or condemn particular moral answers to controversies or dilemmas. There are almost as many ethical theories as there are ethical philosophers. Inmany instances, all ethical theories will converge on a similar set of generally accepted norms and standards of moral conduct. However, many moral theorists contend that a moral approach 
to life consists of more than a hell-or-highwater allegiance to one overarching code of moral rules and principles; there will be a pragmatic willingness to resist hard-and-fast solutions that are supposed to work in all situations.

None of this should be taken to mean that ethical behaviour and decisionmaking is condemned to be irrational or arbitrary, only that what counts and operates as reason is never outside of its informing context. In this way, legal ethics can be viewed less as a fixed and independent code of professional conduct and more as continuing practice within which lawyers construct acceptable norms of behaviour as they struggle to comply with them. To be an ethical lawyer involves more than learning and applying a set of rules; it also demands the cultivation of a critical reflection upon the professional role and responsibilities of lawyers. In short, a fully ethical practice requires an independent sense of moral virtue that involves the life-long development of personal moral character. Because there is no one answer to ethical dilemmas, it does not mean that reasoning can be abandoned or that "anything goes".

In ethical debate, a wide range of answers to arguments can be supported by sophisticated chains of reasoning: moral reasoning is not, therefore, something that stands outside or in judgement on moral decisionmaking, it is made and re-made in the situational process of moral engagement and debate. As such, what counts as a good moral reason is a matter of justification and persuasion, not proof and authority. Accordingly, I do not offer a recommendation that is relativistic (or nihilistic) in which each person's conception of right and wrong is as good as or as valid as anyone else's. While values are constructed with particular social and historical contexts, standards do develop about what is and is not acceptable behaviour, even though those standards are never themselves outside of debate and 
transformation. My approach does have the merit of demanding that, if ethical issues are to be taken seriously, there must be an acceptance that debate and reflection on moral issues is a useful and worthwhile pursuit and that the upshot of such engagement might have an effect upon or make a difference to a person's decisions and actions. Most importantly, it suggests that acting ethically is not about adherence to a code that is resorted to in occasional moments of indecision, but is about the development of a moral way of living and lawyering that encompasses an organic set of attitudes, dispositions and values and that can be incorporated into each lawyer's daily routines and regimen. It is to such a recommendation and its practical implications that I now tum.

\section{Personal and professional}

From a sceptical perspective, therefore, legal ethics is not about perfecting universalisable and enduring codes of conduct. It is about developing a transformative and pluralistic practice that respects the contingent and the particular and allows for diverse answers and appreciations. The traditional concepts and practices of honesty, confidentiality, trust, etc. remain most pertinent, but they are given meaning and bite as the context varies; they are fundamental, but not absolute values in the legal ethics vocabulary. As Lon Fuller pointed out, there is a vast difference between a professional duty that is based on "duty" as opposed to "aspiratiori. ${ }^{13}$ Whereas the former focuses on compliance with a set of rules and concentrates on what is not to be done rather than what ought to be done, the latter speaks in more positive terms and asks professionals to develop a style of practice that inspires ethical 
conduct rather than merely avoids unethical acts. The traditional emphasis on code-based morality breeds a mentality that is more concerned with delineating how far a lawyer can go without engaging in unethical conduct: it tends to privilege social conformity over efforts to build moral character. It is important therefore that lawyers do not internalise the view that it is ethical to do whatever is not prohibited by the professional rules; this is an impoverished and thin view of professional responsibility and legal ethics.

In contrast to understanding the demands of legal ethics as being satisfied by the memorisation of appropriate institutionalised responses to particular factsituations, it ought to be about developing a framework within which to understand and reflect about the inevitable ethical dilemmas that acting as a professional throws up. As such, legal ethics should be a vibrant and dynamic way of being a lawyer that is not something that lawyers simply refer to in stereotypical situations, but is an integral dimension of what it means to be a good lawyer that pervades and infiltrates professionals' whole way of thinking about and acting as lawyers. In developing such a notion and practice of professional ethics, the challenge is neither to abandon a sense of personal morality and defer all ethical responsibility to the unique role and status of the legal professional nor to adhere entirely to the dictates of one's personal conscience and ignore the special responsibilities that attach to being a professional. It is a matter of creating a balance between the two such that it is possible to bring together the professional and the personal in a legal ethics that satisfies the pushes of personal morality and the pulls of professional conduct. To do otherwise is either to relinquish personal responsibility entirely to the self-interested norms of official codes of professional conduct or to ignore entirely the genuine framework of 
professional responsibilities that must influence and affect the dictates of personal conscience. It most definiteJy is not a choice between law and morality, such that the true professional must abandon all efforts to be a good person in being a good lawyer.

Instead of positing professional ethics and personal morality as being entirely separate and, at times, being in direct conflict, it is much more useful and desirable to view one's ethical responsibility as a professional to be part of one's personal morality as an individual. Having developed a personal sense of moral integrity, lawyers should not be faced with the possibility that it will be jeopardised rather than reinforced by the need to subordinate personal values to professional goals. ${ }^{14}$ To ask lawyers to forgo moral judgement is to reduce them to amoral technicians with significant drawbacks and limitations-the practice and defence of a role-differentiation is only sustainable if there is widespread support for and confidence in the institutional processes of law, and this is surely suspect. Ignoring moral considerations, lawyers will begin to be more competitive and less cooperative, more opportunistic and less principled, and more selfregarding and less committed. Moreover, on the basis that lawyers tend to identify more than most with their jobs, the amorality of their professional role will begin to infect their personal lives-the amorality will become its own impoverished morality by default: "lawyers' sensitivities can atrophy or narrow to fit the constricted universe dictated by role". ${ }^{15}$ Strict adherence to a strong role-differentiation asks lawyers to engage in a form of moral schizophrenia. This has considerable costs to lawyers-their sense of moral judgement atrophies; they lose track of what is and is not important; and their clients are reduced to nothing more than fee-generating opportunities. ${ }^{16}$ 
Accordingly, while legal ethics does not simply collapse into personal morality, there has to be a recognition that "role-differentiated behaviour" has a legitimate claim on the attention of those who strive to be ethical lawyers. Although lawyers must assume personal responsibility for their professional activities, it does not mean that they must only do as a lawyer what they would do as an individual (which, in many cases, might tum out to be very extensive). It simply asks them to answer to themselves about the extent of dissonance that a professional-differentiated role should allow. Mindful of the social and political realities in which they offer their professional services, lawyers must confront the consequences of their choices about who to represent, the methods of representation and the broader consequences of their work. If lawyers did permit their own values and preferences to infiltrate all their work, it would mean that lawyers were abusing their privileges by rationing a valuable public service only to those whose views happen to coincide with their own. However, this does not mandate a wholesale abrogation of moral responsibility by lawyers. Instead, it suggests that lawyers should try to better integrate their professional and personal lives. Re-working the balance between role-morality and personal conscience, a fresh account of legal ethics would place the individual at the centre of the process and encourage lawyers to develop a critical morality that encompasses such pressing issues as "what kind of lawyer do I want to be?" and "what interests am I going to spend my life serving as a lawyer?" 17

By asking lawyers to cabin their moral judgement, such advice endangers the whole moral standing of the legal profession. In the traditional approach, there is very little space for reflection or engagement; reference to the rules is intended to provide definitive and authoritative answers. My approach 
suggests that legal ethics has more to do with a practice of situated reasoning and has more to do with the interests, purposes and consequences of the participants and their contexts. Reliance on codes atrophies the moral intelligence and leaves lawyers adrift without a moral compass when those professional rules run out or give conflicting advice: my approach encourages continual reflection and therefore better prepares the lawyer for difficult situations. Indeed, in a manner of speaking, lawyers are in better shape to avoid and resolve ethical dilemmas because their daily regimen requires them to challenge and analyse critically most situations and settings.

The other choice for the enlightened lawyer is to abandon the notion of a professionally differentiated role morality entirely and incorporate all their personal values into the professional arena. This seems an unwise and undesirable move as lawyers will be abandoning their public trust and abusing their monopolistic privileges. The challenge is to integrate the demands of a professional role with the dictates of a personal morality and be able to construct important bridges between the two so that they can each support and fructify each other: one feeds off the other. To provide sound professional judgement, it is necessary to resort to a well-honed and mature sense of moral acuity. Unless one subscribes to a very formalistic account oflaw, a familiarity with and sensitivity to moral issues is an essential quality that all lawyers must have if they are to advise clients about any particular area of law or what the courts are likely to do in any particular case. Without such resources, lawyers will be ill-equipped to fulfill the most basic skills of legal representation; they become only technicians, not advisers. To flinch this challenge or to settle it by default is to fail as both a matter of professional and personal responsibility; it will impoverish both professional and personal 
pursuits.

Also, the traditional approach fails to involve the client sufficiently in the provision of legal services and the fulfilment of client satisfaction. Based on an assumption that has no empirical or theoretical merit, they are seen to have fixed interests and stand outside the moral domain of the lawyer. The reality is that clients rely as much on lawyers to define their interests as they do to protect them. In my approach, the client is treated as a conversational partner who can contribute and be persuaded about particular courses of action and their likely consequences. Indeed, client selection is one of the most important and most neglected issues for lawyers because, once a client is taken on, the lawyer does have some responsibility to treat that person differently than other persons; they are engaged in a special relationship that lawyers cannot simply abandon as and when they choose. Notwithstanding rhetoric to the contrary, lawyers can choose whatever clients they wish. In Canada, there is no equivalent to the English cab-rank rule which requires barristers to accept any client at a reasonable fee in their area of expertise. Consequently, lawyers must take responsibility about and for the clients that they choose to represent.

\section{Practical implications}

The requirement for ethical behaviour and moral character flows from the idea that law is a profession and one in which its members are trustees for the public good in the administration of justice. Dating back to Rome's Theodesian Code and Anglo-Saxon England, lawyers have always been required to take an oath that they will fulfil their professional responsibilities 
in a good and virtuous manner. This is still the case today. New lawyers have to be certified as being of good character and to swear an oath upon admission that they will uphold the highest standards of moral integrity. However, there is very little consensus on what the requirement of moral character entails or demands. Apart from abstaining from criminal or illegal activities (or, at least, not getting caught), law societies treat such inquiries in a pro Jonna way; there is only the most perfunctory inquiry into a person's moral character that is largely confined to the applicant's own admission and answers. Applicants are presumed to be of good character and, therefore, suitable for legal practice unless there is evidence to the contrary. If the requirement of moral character is to be maintained, then law societies must begin to take more seriously its testing and certification. Importantly, the acquisition of legal competence ought not to be treated as equivalent to the establishment of moral character: they are very different and mutually exclusive attainments.

A central problem is that, as one critic astutely observes, the inquiry into moral character is both too early and too late in the overall professional process. ${ }^{18}$ Occurring on entry into the Bar admission courses, it arises before applicants have experienced any genuine ethical dilemmas under real-world pressures; they have no practical context in which to put to the test their ethical intuitions and commitment (or lack of it). However, such institutional assessments occur only after a considerable investment of time and money in academic education by fledging lawyers. Like other skills and requirements, the testing and tutoring of a refined ethical sensibility should be part of a lifelong learning process: there needs to be substantial peer review and a regular auditing process which would both challenge and train lawyers about the 
worth and importance of ethical lawyering. Nevertheless, the question of whether law schools should police the moral character of their students is hotly debated and contested-are law schools primarily academic institutions or gatekeepers for the profession?

Legal ethics is a life-long challenge in which lawyers must be encouraged to go beyond simply learning the rules and how to apply them; they should constantly interrogate themselves and their colleagues about the moral status of their work and practices. Accordingly, lawyers must be helped to hone and question a sense of moral judgement about themselves and their work. While many lawyers lead ethical lives and carry much of that over into their professional lives, there is still a depressing indifference to issues of legal ethics and a lamentable ignorance about how to identify and deal with situations that raise ethical queries and challenges. The first task, therefore, is for people to enhance and interrogate their own sense of moral judgement and responsibility; this is too often assumed to be in place. Mindful that ethical training is primarily concerned with learning about oneself, students need to confront ethical dilemmas in concrete circumstances in order to begin to discover (or construct), question and articulate their own moral views before they struggle with the complex demands of a professional ethic. There is an urgent need to stimulate the moral imagination and cultivate each person's sense of moral responsibility, such that they are able to develop a moral facility that is capable of recognising ethical dilemmas, analysing them, and responding to them in a responsible and realistic way. A pervasive difficulty in achieving this is that legal ethics is more about responsibilities than rights and, therefore, does not sit easily or well with much of the legal education that lawyers receive. 
Insofar as the practice of legal ethics is in disarray, the law societies and the law schools must shoulder a considerable share of the blame for failing to provide an institutional setting for establishing a sophisticated understanding of professional responsibility and its demands. Few law schools take very seriously the need to offer training of a mandatory or optional kind to its graduates. Certainly, the extent and sophistication of courses in legal ethics comes nowhere close to mirroring those of the substantive courses. Furthermore, the courses that do exist tend to treat the teaching of legal ethics as if it were simply one more course, with the same intellectual ambitions and pedagogical techniques as business association or torts. In an important sense, although law schools have not taken the teaching of legal ethics seriously, they have still instilled within students and lawyers a certain sense of professional ethics. Indeed, law schools cannot avoid teaching legal ethics as "the very act of teaching ... creates images of law and lawyering when we teach doctrine through cases and hypotheticals". 19 Unfortunately, reinforced by the general rule-centred attitude to the study of legal doctrine, law students settle neatly into thinking of legal ethics as involving a similar process of role-detachment and legalistic application.

To their credit, however, the law societies and law schools have begun to take their own responsibility in meeting this shortcoming much more seriously. Stirred into action by some first-rate studies and reform proposals, ${ }^{20}$ there is now a compulsory component in most provincial Bar admission courses. Nevertheless, there is still a considerable way to go as instruction remains closely tied to the rote-learning of the codes and the tendency to treat legal ethics the same as other subjects remains pronounced. All in all, therefore, the efforts to prepare young lawyers for the ethical rigours of legal 
practice are still very limited and more an afterthought than a core feature of the curriculum. It will take a sea-change in both the scope and substance of courses taught and the style and pedagogy through which they are presented.

As well as altering their attitudes and approach to the teaching of legal ethics, law societies must encourage their members to adopt a much more expansive understanding of their ethical responsibilities. It can do this in a number of ways. At an institutional level, lawyers can be constantly reminded that they must not neglect or overlook the opportunity to converse with other lawyers. This can be done by proliferating the forums-in law schools, in professional gatherings, in law firms, etc.-within which dialogue and engagement can be nurtured and thrive. In this way, lawyers might explore their own moral intuitions in the testing context of others' views without risking public criticism or risk. Also, it can be made clear to lawyers that their moral obligations as professionals extend beyond concern with their own individual actions and should encompass a responsibility to monitor the actions of other lawyers. In this way, professional responsibility is as much a collective as well as personal undertaking in which each lawyer should contribute to the moral health of the profession as a whole.

\section{Conclusion}

As with so much else, de Tocqueville was not only half right about his assessment of (American) lawyers when he wrote, but his conclusions remain equally valid and invalid today. He was surely accurate in his pronouncement that lawyers constituted the new aristocracy of society. However, he was well wide of the mark in believing that such an elite status was warranted because 
the legal profession functioned as the enlightened and sensible guardians of the public good. $^{21}$ Although traditional versions of legal ethics are still defended in the name of public service, there are few lawyers who conduct their daily professional lives in such a spirit. It is unrealistic to imagine or expect that every lawyer will, like Socrates, only be guided by the need to do right rather than wrong: most lawyers are reasonably concerned about their jobs, paying their mortgages, providing for their kids, etc. Indeed, there is ample evidence to demonstrate that lawyers will hold to ethical principles when it is in their interests to do so or, more accurately, when their financial considerations coincide with their ethical ones. ${ }^{22}$ However, it is neither unreasonable nor unrealistic to expect that they can be persuaded, collectively and individually, to accept the noble challenge of redeeming the legal profession's moral standing and of fashioning a fresh image of legal ethics and professional responsibility that serves a fragmented society.

At the heart of any efforts to reaffirm the profession in its own and the public's moral esteem must be the commitment to emphasise that lawyers need not and should not spend the bulk of their professional lives doing what they would shy away from in their personal lives. Can it really be appropriate that lawyers should act in wilful disregard of moral considerations which would weigh heavily on them and others in their personal lives? In short, lawyers must stop asking whether a good lawyer can be a bad person and begin providing answers to how good persons and good lawyers can co-exist in the same person. This is a task that all lawyers should relish. Moreover, legal ethics should not be thought of as something that arises in discrete and exceptional circumstances. Everything that lawyers do, from the selection of clients to their involvement in civic affairs, implicates and reflects a lawyer's 
approaches and understanding of what it means to be an ethical lawyer. A lawyer who appreciates the full import of what it demands to be an ethical lawyer understands that ethical considerations are at the heart of lawyering, not a peripheral concern. To be a good person and a good lawyer need not be the oxymoron that Plato and more modern pessimists seem to believe it to be.

\section{Acknowledgements}

I am grateful to Jennifer Blitz and Lisa Csele for their research assistance. 


\section{Notes}

[1] See D. Coquillette, Lawyers and Fundamental M oral Responsibility (Cincinnati, Anderson Publishing Company, 1995). The Canadian literature on legal ethics and professional responsibility is scarce. For a collection of the available literature, see Legal Ethics in Canada: Theory and Practice

D. Buckingham et al. (Eds) (foronto, Harcourt Brace, 1996).

[2] See R. Cranston, Legal Ethics and Professional Responsibility (Oxford, Clarendon Press, 995).

[3] This essay builds upon a project that I begun in an earlier piece. For a fuller elaboration of the traditional model and critique, see Hutchinson, Calgary and everything after: a postmodern re-vision of lawyering (1995) 23 Alta Law Review 768.

[4] See A. Goldman, The Moral Foundations of Professional Ethics (fotowa, NJ, Rowman and Littlefield, 1980).

[5] See R. Abel, American Lawyers (New York, Oxford University Press, 1989) and The Legal Profession in Engand and Wales (Oxford, Blackwells, 1988).

[6] D. Stager and H. Arthurs, Lawyers in Canada 159 (foronto, Statistics Canada and University of Toronto Press, 1990).

[7] Arthurs, Lawyering in Canada in the 21st century (1996) 15 Windsor Yearbook of Access to Justice

202 (Windsor, Ontario, Faculty of Law, University of Windsor).

[8] See Abel, Why does the ABA promulgate ethical rules? (1981) 59 Texas Law Review 639 and Rhode, Why the ABA bothers: a functional perspective on professional codes (1981) 59 Texas Law Review 689.

[9] See Arthurs, Climbing Kilimanjaro: ethics for postmodern professional (unpublished ms, 1995).

[10] See A. Hutchinson, It's All in the Game: a Non-foundation Account of Law, Politics and Adfudication (Durham, NC, Duke University Press, 1998). Of course, my proposal is not only that legal ethics should change, but also the legal enterprise generally.

[11] See Simon, The trouble with legal ethics (1991) Journal of Legal Education, 65.

[12] See generally Symposium-critical theories and legal ethics (1993) 81 Georgetown Law Journal 2457 and Symposium-teaching legal ethics 58(3 and 4) Law and Contemporary Problems (Durham, NC, School of Law, Duke University, 1995).

[13] See L. Fuller, The Morality of Law (New Haven, Yale University Press, 1969).

[14) See Kupfer, Authentic legal practices (1996) IO Georgetown Journal of Legal Ethics

33. [15) Wasserstrom, Lawyers as professionals: some moral issues (1975) 5 Human

Rights 1 at 5.

[16) See Postema, Moral responsibility in professional ethics (1980) 55 New York University Law Review

73.

[17) See Esau, What should we teach? Three approaches to professional responsibility (1987) Legal Education in Canada 311.

[18) See R. Gerber, Lawyers, Courts and Professionalism: The Agenda for Reform 66 (New York, Greenwood Press, 1989).

[19) Menkel-Meadow, Can a law teacher avoid teaching legal ethics (1991) 14 J Journal of legal Education 3. 1991.

[20) See, for example, B. Cotter, Professional Responsibility Instruction in Canada (Montreal, Conceptcom, 1992) and Legal Ethics in Canada: Theory and Practice D. Buckingham et al. (Eds) (Toronto, Harcourt Brace, 1996). For my own efforts to put practical flesh on this theoretical skeleton, see

A. Hutchinson, Legal Ethics and Professional Responsibility: A Critical Introduction (Toronto, Irwin Books, 1999).

[21) See A. De Tocqueville, Democracy in America 200-04, H. Reeve trans. (New York, Schocken Books, 1961).

[22) See J. Carlin, Lawyers on their Own: A Study of Individual Practitioners in Chicago (New Brunswick,

NJ, Rutgers University Press, 1962). 